\title{
Combating Illegal Movement of Radioactive Materials and Objects Across the State Border of Ukraine
}

\author{
- Nikiforenko Volodymyr, PhD in Public Administration \\ Administration of the State Border Guard Service of Ukraine, Kyiv, Ukraine \\ ORCID: https://orcid.org/0000-0003-1452-2312
}

This article, by using general scientific methods, presents the main issues and ways to improve the appropriate technical equipment of state border crossing points, legal responsibilities of the State Border Guard Service of Ukraine and the main results of operational activities to combat the illegal movement of radioactive materials and objects across the state border. The article shows the results of international cooperation and the implementation of international technical assistance projects by the State Border Guard Service of Ukraine on improving the system of prevention of illicit trafficking of radioactive materials and objects.

Furthermore, the article examines the main responsibilities of the State Border Guard Service of Ukraine on ensuring radiation safety, which affects the real needs of equipping the state border guard bodies with the necessary technical tools. It is indicated that the detection of suspicious objects at state border crossing points may be limited to detection of exceeding the permissible radiation level without details about its kind with their further transfer to specially authorised state authorities of Ukraine for detailed examination.

It is essential to note the need to improve the legal regulation of illegal trafficking of materials and objects that are hazardous radioactive sources across the state border considering negative economic and social consequences to the person, society, state and international community. There is an urgent need for well-defined regulation regarding the radiation materials and objects to prevent their movement across the state border without obtaining a special permit.

Taking into account the need to reduce the budget expenditure of the border agency, this article provides recommendations to determine the purpose of the state re-equipment program of state border crossing points with modern tools for detection of radiation sources.

Keywords: border control, improvement of radiation control, radiation control, radiation control at border crossing points, radiation control system at the state border, radiation safety.

(C) Nikiforenko V., 2021

\section{Introduction}

Real threats of illegal trafficking of radioactive materials and objects require state authorities to take comprehensive measures to counter their illegal movement across the state border. Yes, there are both external and internal threats of such illegal activities in Ukraine.

Radioactive materials can be imported by the members of cross-border terrorist groups, stolen from institutions and organizations that legitimately use them for scientific or industrial purposes. The source of radiation threat can also be illegally moved from the 30-kilometre exclusion zone near the Chornobyl nuclear power plant.

The State Border Guard Service of Ukraine is a subject of national security. Its state border guard authorities have been implementing for a long-term international project «Global Partnership against the Proliferation of Weapons and Materials of Mass Destruction» with the support of the U.S. Threat Reduction Agency to prevent the proliferation of radioactive (nuclear) materials at the state border and the U.S. Department of Energy under the «Second Line of Defence» program [1, p. 127]. At the same time, a technical system for counteracting illegal trafficking of the radioactive materials and objects needs to be improved to respond to the conditions of hybrid warfare against Ukraine.

\section{Analysis of academic literature and problem identification}

Nuclear safety issues were researched by B. Sandstrom, D. Moore, P. Minnebo, B. McLean, L. Jones, C. Hammond, B. Jenkins, G. Plachkov, S. Kondratov. Ways to improve the technical 
arrangement of state border crossing points are covered in the papers of B. Parka, O. Melnikov, Y. Vyniarskyi, O. Karpenko, O. Dmytrenko and other researchers. At the same time, contemporary issues of maintaining the radiation safety border monitoring system at the required level remain insufficiently covered. The statistical data is introduced into the scientific circulation covering results of operational and service activities of the state border detachments of the State Border Guard Service of Ukraine on counteracting radioactive materials and objects illegal trafficking. Furthermore, the difficulty of installing stationary radiation control systems at most Ukrainian railway state border crossing points has already prompted the American party of the international project to start a joint search with the State Border Guard Service of Ukraine to find the most appropriate technical solution of this problem.

The purpose of the article is to determine ways to improve the technical equipment of state border crossing points using general scientific methods, legal responsibilities of the State Border Guard Service of Ukraine and the main results of operational and service activities on counteracting illegal movement of radioactive materials and objects across the state border.

\section{Research materials}

Regulation of the State Border Guard Service of Ukraine on radiation safety. Resolution of the Cabinet of Ministers of Ukraine No. 813 of 2 June 2003 identified two signs of illegal trafficking of radioactive materials. The first is that nuclear materials, radioactive waste and radiation sources remain outside of the state systems of accounting and control of radioactive materials, as well as systems of their physical protection (except for generating technical devices that create or under certain conditions can create radiation). The second is carrying out operations with radioactive materials without compliance with the requirements established by the law (purchase, storage, use, transfer, change, destruction, transportation, disposal) [2].

According to O. Melnikov, Y. Vyniarskyi and O. Karpenko, detection of radioactive materials at state border crossing points of Ukraine can be carried out by using stationary systems, personal devices of radiation control, as well as verification of transport documents and cargo marking. The purpose of their use should be to identify special materials used in nuclear weapons (including plutonium and uranium). The level of hazard for personnel performing tasks at state border crossing points is considered an indicator exceeding $0.1 \mathrm{~m}^{3} \mathrm{v} / \mathrm{h}[1, \mathrm{p} .126]$.
At the same time, the regulatory determination of the radiation materials and objects level that can move across the state border is not legally established, which adversely affects: transparency of throughput operations at state border crossing points; possibility of conflict situations; planning of development of technical arrangement of border infrastructure [1, p. 126].

It is essential to note that terrorist groups can illegally move «radiological dispersion devices» across the state border. They can lead to massive disorganization of the population and significant economic losses arising during the elimination of the consequences of radiation contamination of the territories.

In the inspection of detected radioactive materials and objects representatives of territorial bodies of the Ministry of Emergencies of Ukraine, Ministry of Environmental Protection and Natural Resources of Ukraine, State Health and Epidemiological Service of Ukraine and the State Nuclear Regulatory Inspectorate were involved.

Protection and maintenance of suspicious materials and items during their transportation is carried out by the territorial authorities of the Ministry of Internal Affairs.

The state border protection authorities of the State Border Guard Service of Ukraine carry out the initial examination of detected suspicious materials, objects, as well as the preliminary establishment of the boundaries of the controlled zone in case of their detection during border control at local state border crossing points, in which there are no environmental control posts of the Ministry of Environmental Protection and Natural Resources of Ukraine, or during the detention of persons and vehicles that tried to illegally cross the state border outside the border crossing points. Border guards can also be involved in the protection and maintenance of suspicious materials or items during their transportation if they are detected when trying to illegally move across the state border outside the border crossing points [2].

In November 2020, by the virtual signing of the joint statement by the National Nuclear Security Agency (NNSA) and the Administration of the State Border Guard Service of Ukraine, the parties confirmed mutual commitments to continue joint efforts to prevent the smuggling of nuclear materials along the state border. This cooperation envisages: installation of radiation control systems at more than 90 international state border crossing points, airports and ports within Ukraine; equipping radiation control systems on internal border crossing points with the occupied and Russian-controlled territories in the AR of Crimea and certain districts of Donetsk and Luhansk regions; deployment of 14 field mobile radiation detection systems; 
ensuring specialized training of law enforcement officers on combating the smuggling of nuclear materials; maintenance of radiation control systems and equipment [3].

The state of equipping state border crossing points of Ukraine with technical means. Today, from the total number of 230 state border crossing points and checkpoints, only 82 are equipped with stationary systems of automated control over the movement of radioactive substances and nuclear materials (including for road traffic -63 , rail -1 , air -6 , sea -10 , ferry and river -2 ).

During the period of implementing joint program «Detection and cessation of nuclear smuggling» with the U.S. Department of Energy during 2005 - 2020, stationary radiation control systems were installed at 95 state border crossing points. Of these, 13 were in the temporarily occupied territory of Ukraine. Furthermore, mobile radiation control systems are installed at 3 entry and exit border crossing points in the territories of Donetsk («Marinka»), Luhansk («Stanytsia Luhanska») and Kherson («Kalanchak») regions.

Currently, there are 52 stationary radiation control monitors "Yantar» and 30 «TSA». Their main technical characteristics are presented in Table 1. They are used to signal a dramatic change in the natural radiation background when control objects pass throw them.

Technological schemes of border control stipulate that these technical means are used for radiation monitoring, which doesn't involve distinguishing radiation types. In case border guard detachments detect suspicious materials and objects, other government agencies and services take the materials and objects for further examination by qualified personnel [1, p. 129].

Since 2019, the State Border Guard Service of Ukraine, with the support of the U.S. Department of Energy within the International Technical Assistance Program «Detection and Termination of Nuclear Smuggling» (NSDD), has developed and implemented its own maintenance system for existing stationary means of detecting nuclear and radioactive materials. This experience was interesting for Egypt, Nigeria, Lebanon. At present, through the organization of the IAEA, the issues on the organization of appropriate training of representatives of these countries on the basis of the Main Training Center for personnel of the State Border Guard Service of Ukraine of Major General Igor Momot are underway [4].

State border crossing points of Ukraine, which for financial reasons are not yet equipped with stationary monitors are provided with a sufficient number of portable devices that allow detecting attempts of illegal trafficking of radioactive substances, objects and nuclear materials by measuring radiation level. They are classified as pocket; portable. In addition, the state border guard has a need to use chemical and radiological laboratories, which allows fulfilling the main task of the border agency: minimization of potential threats to the health of personnel, border guards and participants of checkpoints at checkpoints across the state border [1, p. 129], [5, p. 40].

Table 1 - The main technical characteristics of stationary radiation control monitoring used at state border crossing points of Ukraine

\begin{tabular}{|c|c|c|c|c|c|c|}
\hline \multirow{2}{*}{ No. } & \multirow{2}{*}{ Main characteristics } & \multirow{2}{*}{ Units } & \multicolumn{2}{|c|}{ Stationary car monitors } & \multicolumn{2}{|c|}{ Stationary pedestrian monitors } \\
\hline & & & TSA VM250 & Yantar 1-A & TSA PM700 & Yantar 1-P \\
\hline 1 & Sensitivity & & & & & \\
\hline 1.1 & ${ }^{239} \mathrm{Pu}$ & g & 10 & 10 & 0,08 & 1 \\
\hline 1.2 & ${ }^{235} \mathrm{U}$ & g & 1000 & 1000 & 10 & 10 \\
\hline 1.3 & ${ }^{239} \mathrm{Pu}$ (shielded) & g & 200 & 50 & 120 & 20 \\
\hline 2 & Area gamma detectors & $\mathrm{cm}^{3}$ & 4332 & 4600 & 4332 & 4600 \\
\hline 3 & $\begin{array}{l}\text { Number of neutron } \\
\text { detectors }\end{array}$ & Piece & $4\left(8^{*}\right)$ & 4 & $1\left(8^{*}\right)$ & 2 \\
\hline 4 & $\begin{array}{l}\text { Speed of movement of } \\
\text { the control object }\end{array}$ & $\mathrm{km} / \mathrm{h}$ & 8 & 15 & \multicolumn{2}{|c|}{ normal pace walking } \\
\hline 5 & Weight & $\mathrm{kg}$ & 362 & 350 & 318 & 170 \\
\hline
\end{tabular}

Note: * - Number of neural detectors complete with hypersensitivity 
Table 2 - Number of detected cases of radiation sources at border crossing points of Ukrainecrossing points of Ukraine

\begin{tabular}{|c|l|c|c|c|c|c|}
\hline No. & \multicolumn{1}{|c|}{ Period } & Food & $\begin{array}{c}\text { Military } \\
\text { equipment }\end{array}$ & Ferrous metals & Equipment & Total \\
\hline 1 & 2018 & 1 & 2 & 1 & 2 & 6 \\
\hline 2 & 2019 & & 5 & & 5 & 10 \\
\hline 3 & $2020(10$ month) & & 1 & & 2 & 3 \\
\hline 4 & Total & 1 & 8 & 1 & 9 & 19 \\
\hline
\end{tabular}

Currently, the following pocket and portable technical means are used during border control at state border crossing point:

Dosimeter-radiometer ISS-05 «TERRA»; dosimeter-signaler search engine Polimaster 1703 GNA;

dosimeter-signaler search engine DKS-02-PN «Kadmiy»;

dosimeter-radiometer ISS-07 «Search»;

ISS-11 GN «Spectre»;

universal dosimeter-radiometer «ISS-03».

Technical means of radiation control at state border crossing points perform the following functions: detection of relevant materials and objects; alerting staff about the hazard; deterring persons from this type of unlawful activities $[5$, p. 40]. At the same time, the fundamental difference between stationary systems is the ability to minimize the negative impact on the results of operational and service activities of the human factor. In particular, concerning the distance of personnel from control functions, minimization of risks of its entry into corruption and other illegal activities, guaranteeing $100 \%$ control of all objects.

Training of personnel on counteracting illegal trafficking of radioactive materials is carried out by the State Border Guard Service of Ukraine in educational institutions of the agency. This has allowed to introduce a system of phased planned retraining of servicemen of the state border guard bodies; conduct field training, seminars with staff, which directly perform the tasks of border control at state border crossing points. The measures taken have led to a decrease in the number of technical means [6, p. 20].

The main results of the State Border Guard Service of Ukraine on counteracting the illegal trafficking of radioactive materials and objects. The main characteristics of the suspected material or subject include: its appearance; presence of markings, warning inscriptions on radiation hazards; physical and chemical characteristics that allow drawing conclusions about their purpose, properties and hazards [2]. Within its area of responsibility, the State Border Guard Service of Ukraine at state border crossing points of Ukraine may detect suspicious objects, whose main classification feature is the excess of radiation levels over the natural background.

Thus, during 2018-2019 and 10 months of 2020, the State Border Guard Service of Ukraine detected 19 radiation sources at state border crossing points of Ukraine, which are accounted for in the departmental Information and Telecommunication Database «HART-5». Taking into account similar inspections by the neighbouring states' control services, $84 \%$ of radiation sources were detected in the exiting passenger and transport flows. Classification features of detected radiation sources are presented in Table 2. The main threatening objects of control are military equipment and tools, much of which are clocks that in the Soviet era were installed on military aircrafts.

In addition, border guard detachments of the State Border Guard Service of Ukraine found the inconsistencies with the radiation safety regime requirements in areas exposed to radioactive contamination, which is stipulated by Article 46-1 of the Code of Ukraine on Administrative Offenses.

From 1993 to 2018, the International Atomic Energy Agency accounted for 3,497 incidents. 285 are considered to be confirmed for malicious use of radioactive materials ( 5 of them took place in 2018) [7]. The presence of real radiation safety threats in the post-Soviet space indicates the fact of confiscation of $2 \mathrm{~kg}$ of highly enriched uranium in 1994 in Prague, which was moved by train from Moscow to Warsaw through Minsk [5, p. 36].

The State Border Guard Service of Ukraine continues to work on improving the system of prevention, detection and cessation of attempts to illegally move radioactive substances and nuclear materials across the state border. Taking into account the specifics of the tasks assigned, it is considered appropriate to equip border crossing points with radiation hazard indicators. 
Detailing the specific characteristics of radiation of suspicious materials and objects to be carried out by full-time specialists of the relevant state executive authorities.

The impossibility of further acquisition of stationary monitoring systems and spare parts for them in the Russian Federation, which carries out aggressionagainstUkrainerequiresthedevelopment of a state program for the re-equipment of state border crossing points by modern technical means of radiation control. To this end, it is advisable to pay attention to the achievements in the field of production of semiconductors allowing detection of high-energy particle flows.

As an example, a PIN-RD100 semiconductor has an active surface of $100 \mathrm{~mm}^{2}$, OSD35-LR - $34.2 \mathrm{~mm}^{2}$. Modern semiconductors can work in the mode of direct radiation power calculation or turning it into the visual range of electromagnetic waves [8]. These devices can be combined in the matrix to increase the plane of the sensitive surface of the technical tools for radiation indication. This enables the construction of compact and economic devices for the detection of suspicious items. Technical devices with their use are easily integrated into computer networks.

\section{Conclusion}

Thus, the urgent issue currently remains the need to improve the legal regulation regarding combating the illegal movement of materials and objects that are hazardous radiation sources across the state border taking into account negative economic and social consequences to the person, society, state and international community. In particular, there is a need for well-defined regulation regarding the radiation materials and objects to prevent their movement across the state border without obtaining a special permit.

Within the responsibilities of the State Border Guard Service of Ukraine, the function of ensuring radiation safety is to detect exceeding the permissible radiation level without detailing its species. When identifying suspicious materials and items, the state border guard authority has to inform the local unit of the State Service of Environmental Inspection of Ukraine, local authorities and other interacting state agencies. Experts of the State Service of Environmental Inspection of Ukraine should make decisions on additional laboratory tests, cargo seizure or the possibility of its movement across the state border of Ukraine on the results of additional instrumental inspections. This allows simplifying the requirements for process equipment of state border crossing points.

The purpose of the state program for reequipment of state border crossing points with modern tools for radiation source indication should be: priority equipping with monitoring radiation stationary means where they have not yet been installed; gradual replacement of technical means produced in the Russian Federation; conducting and participating in scientific research on the development of modern samples of technical means for radiation indication; use of international technical assistance programs. This will reduce the border agency's budget expenditures for the development and maintenance of the relevant technical infrastructure at state border crossing points.

Further research area may be the optimization of the technology for detecting radiation sources among cargoes moving through state border crossing points of Ukraine.

\section{References}

1. Melnykov, O., Viniarskyi, Ya., Karpenko, O. (2012). Features of nuclear detection and radioactive materials at the border in the context of general security of the state. Modern special equipment, 4(31), 125 - 134.

2. On approval of the procedure for interaction of executive bodies and legal entities carrying out activities in nuclear energy use in case of detection of radioactive materials in illegal trafficking. Resolution of the Cabinet of Ministers of Ukraine No. 813 dated 2 June 2003. Retrieved from: https://zakon.rada. gov.ua/laws/show/813-2003-\%D0\%BF\#Text.

3. Representatives of NNSA and the Administration of the State Border Guard Service of Ukraine (ASBGS) recently signed a joint statement reiterating their commitment to work together to fight nuclear smuggling. 20 of November 2020.Retrieved from: https://dpsu.gov.ua/en/news/united-states-and-ukrainereaffirm-commitment-to-fight-nuclear-smuggling.

4. At checkpoints, 30 stationary nuclear material detection systems were tested. 18.04.2019. Retrieved from: https://mvs.gov.ua/ua/news/20012_DPSU_Na_punktah_ propusku_perevireno_30_stacionarnih_sistem_viyavlennya_ yadernih_materialiv.htm.

5. Dmytrenko, O. (2019). Justification of recommendations for the staff of the State Border Guard Service to combat the smuggling of nuclear materials at state border crossing points. Collection of scientific papers of the National Academy of the State Border Guard Service of Ukraine. Series: military and technical sciences, 3(81), 32 - 47. doi: 10.32453/3.v81i3.436.

6. Kuznetsov, M. (2018). Powers of the State Border Guard Service of Ukraine and regulatory control. Economics and customs relations, 4, $18-22$.

7. IAEA incident and trafficking database (ITDB) incidents of nuclear and other radioactive material out of regulatory control 2019 Fact Sheet. Retrieved from : https://www.iaea.org/sites/ default/files/19/04/itdb-factsheet-2019.pdf.

8. High breakdown voltage, fully depleted series large active area photodiodes. Retrieved from: https://docs.rsonline.com/558c/0900766b816684f7.pdf. 


\section{Протидія незаконному переміщенню через державний кордон України радіоактивних матеріалів та предметів}

\section{Нікіфоренко В. С.}

Адміністрація Державної прикордонної служби України, м. Київ, Україна

У статті з використанням загальнонаукових методів, нормативно визначених повноважень Державної прикордонної служби України та основних результатів оперативно-службової діяльності з питань протидії незаконному переміщенню через державний кордон радіоактивних матеріалів та предметів наведені основні проблемні питання та шляхи удосконалення відповідного технічного облаштування пунктів пропуску через державний кордон. Показані результати міжнародної співпраці та реалізації Державною прикордонною службою України проєктів міжнародної технічної допомоги з питань удосконалення системи запобігання незаконному обігу радіоактивних матеріалів і предметів.

Розглянуто основні повноваження Державної прикордонної служби України з питань забезпечення радіаційної безпеки, що впливають на реальні потреби комплектування органів охорони державного кордону необхідними технічними засобами. Зазначено, що виявлення підозрілих предметів у пунктах пропуску через державний кордон може обмежуватись виявленням перевищення допустимого рівня іонізуючого випромінювання без деталізації його виду з подальшою передачею їх для детального дослідження спеціально уповноваженим державним органам виконавчої влади України.
Акцентовано увагу щодо необхідності удосконалення правового регулювання незаконного обігу через державний кордон матеріалів та предметів, що $є$ джерелами небезпечного радіоактивного випромінювання з урахуванням шкідливих для особи, суспільства, держави та міжнародної спільноти негативних економічних та соціальних наслідків. Визначено нагальну потребу чіткого регламентування норм радіаційного випромінювання матеріалів та предметів, що можуть переміщуватись через державний кордон без отримання спеціального дозволу.

3 урахуванням необхідності зменшення витратної частини бюджету прикордонного відомстванаведенірекомендаціїщодовизначення мети державної програми переоснащення пунктів пропуску через державний кордон сучасними засобами індикації джерел іонізуючого випромінювання.

Ключові слова: засоби радіаційного контролю, прикордонний контроль, радіаційна безпека, радіаційний контроль у пунктах пропуску, система радіаційного контролю на державному кордоні, удосконалення радіаційного контролю.

Отримано 13.01.2021 